\title{
Consumer Animosity Following International Crisis: A Conceptual Framework to Understand Indonesian Consumers' Attitude towards Australian Products
}

\author{
Daniel $\mathrm{Koh}^{1}$ \\ ${ }^{1}$ Singapore Management University, Singapore \\ Correspondence: Daniel Koh, Singapore Management University, Singapore. E-mail: danielkoh@smu.edu.sg
}

Received: March 20, 2014

Accepted: August 28, 2014

Online Published: September 25, 2014

doi:10.5539/ijbm.v9n10p21

URL: http://dx.doi.org/10.5539/ijbm.v9n10p21

\begin{abstract}
Over the past three decades, the topic of consumer animosity has attracted the interest of academics, researchers, and policy makers. Researchers have attempted to understand the underlying constructs that lead to consumer's animosity using conceptual models to explain antecedents and consequences of consumer's animosity. This study revisits the social construct of individualism-collectivism and further refines the model with an additional psychological construct-the level of tolerance. The framework proposes that (i) individualistic-collectivistic behaviour in high-low cosmopolitanism society affects the sensitivity of consumers' animosity and (ii) consumers' distinct, non-bipolar affinity expressed through level of tolerance interacts with consumers' animosity to create a net willingness to buy foreign products from hostile nation. It then ends with some managerial implications, along with some possible avenues of further research.
\end{abstract}

Keywords: consumers' animosity, ethnocentrism, Nation brand

\section{Introduction}

In November 2013, Indonesia summoned the Australian Ambassador in Jakarta over spying allegations. Following that, Indonesians condemned "the Australian government for its wiretapping activities against Indonesia" and they demanded that Canberra apologize. A former Australian minister then made a comment, saying that "an apology is the least Australia can offer now and, even with one, a long and rocky ride is inevitable...the most valuable currency in international diplomacy is personal trust and we breach that at our peril" (Perdani, 2013). An Indonesian minister then urged a boycott of Australian beef over the spying row (Bachelard, 2013).

On a separate matter, The Australian (2012) reported that "a coalition government will instruct the navy to turn around asylum-seeker boats on the water and return them to Indonesia in an assertion of Australian border protection." (Kelly, 2012) This instruction arose when relationship between Indonesia and Australia turned sour over the Turning Back the Boats policy. But this relationship turns warmer when Indonesian Foreign Minister Marty Natalegawa said that he is "reassured" [the turning back the boats policy] is not a breach of Indonesian sovereignty, and he believes that, with "co-operation", the two countries can work out on the technical aspect (Bolt, 2013). However, relationship still wasn't soothed as House of Representatives defense, intelligence and foreign affairs committee member Susaningtya Handayani Kertopati commented that "the greatest threat Indonesians face obviously comes from Australia.” (Witular, 2014).

Both sensitive matters - the wiretapping activities and turning back the boat policy - weren't just security and cross border issues but economic links that could damage mutual and lasting benefit, such as from trade and tourism (Fray, 2014). It is then expected that consumers turn protectionists in response to such a hostility. Such reactions can deepen consumers' animosity and finally impact consumers' willingness to buy foreign products from hostile nation.

Much research has been done on consumers' animosity and its antecedent and effects but little effort has been made to study the consumers' level of transcendence (i.e. level of tolerance) that interacts with consumers' animosity at the country-specific level. Moreover, we observe that the measure of a society's individualism-collectivism does affect the sensitivity for animosity against the offending country. This paper 
explores the antecedents of consumers' animosity by adding a new construct-consumers' level of transcendence or tolerance - and use it to refine existing theoretical model on consumers' animosity.

\section{Consumers' Animosity}

Animosity refers to strong emotions of dislike based on beliefs arising from military, political, or economic hostility between nations and peoples that are perceived to have violated social norms (Averill, 1982). Animosity also refers to remnants of antipathy, or hostility towards a country (Klein et al., 1998; Riefler \& Diamantopoulos, 2007). Researchers in marketing have broadly classified animosity into two categories: (i) situational animosity, and (ii) stable animosity. Situational animosity is defined as animosity that arises from situations that violate social norms through hostile actions. Stable animosity is defined as animosity that arises from events that warrant a deeper impression of hostility such as war between nations. Both types of animosities contribute to consumers' overall animosity.

Leong et al. (2006) argued that external attribution (Weiner, 1986, 2000) and perceived external control (Fedem, 1985) increase situational animosity. Consumers attribute external factors for an explanation of reasons behind motives for animosity. In addition to this external attribution, situational animosity by itself may also accumulate to stable animosity, resulting to stronger antagonism and unhappiness. To better understand consumer's animosity, the two item classification is further refined into four items: (i) national situational, (ii) personal situational, (iii) national stable, and (iv) personal stable. (Jung et al., 2002; Ang et al., 2004) National situational animosity refers to "animosity arising from a current specific circumstance that has repercussions at the national level". Personal situational animosity refers to animosity that "arises out of repercussions felt at a personal level". National stable animosity refers to animosity arising from historical circumstances that has ramifications at the national and, over time, has become embedded as a prevailing inclination. Personal stable animosity refers to dispositional animosity that affects individuals at a personal level. Asians typically regard situational animosity with a foreign country that gives economic issues and stable animosity with a foreign country that gives national issue such as War. (Jung et al., 2002) Shoham et al. (2006) have attempted to identify three types of animosities: (i) dogmatism, (ii) nationalism, and (iii) internationalism. Dogmatic animosity refers to animosity felt in the individual level. Nationalistic animosity refers to animosity felt at the national level whereby an impact in national image or reputation affects an individual. Internationalistic animosity refers to animosity felt at the international level. Alden et al. (2013) also offers an explanation for global level construct being an influence on consumers' animosity.

The direction of this paper looks into national-situational animosity that arises from international level crisis. In this paper, economic issues are more apparent as compared to war issues and larger countries with higher levels of foreign trade can instigate deeper animosity as compared to smaller countries with lower level of foreign trade. (Le Vine \& Campbell, 1972; Russell \& Russell, 2006)

Consumers' animosity has a direct impact on consumers' willingness to buy foreign products from hostile nation. (Klein, Ettenson, \& Morris, 1998) When consumer animosity is weak, negative impact remains evident on willingness to buy. (Cui, Wajda, \& Hu, 2012) Unlike ethnocentrism where consumers choose local products over foreign products (Shimp \& Sharma, 1987), consumers' animosity involves choosing products from different foreign countries. (Klein, 2002) When consumers reject products from hostile nation, changes are required to allow global advantage (Amine, Chao \& Arnold, 2005 \& Pamar, 2004). Consumers' boycott of foreign products from hostile nation may also occur; heightened boycotting activities lead to lower likelihood of consumers purchasing products from offending countries (Mrad, Ye Sheng \& Hart, 2013). Looking from the consumers' perspective, boycotting discontinues egregious behaviour or policy and it displays consumers' power by affecting companies' bottom-line (Braunsberger \& Buckler, 2011). If consumers accept products from hostile nation, product quality supersedes animosity and hostility (Elliott \& Cameron, 1994), resulting to a phenomenal observation of favour in quality over hostility. Changes to improve hostile situation and leverage on product quality that supersedes hostility will improve measurement of brand equity even in the face of animosity. (Park \& Srinivasan, 1994, for measurement of brand equity) Cases for consumer's animosity were apparent in history; American boycott French food and wines (Ebenkamp, 2003), German boycott American goods over Iraq War (Kirschbaum, 2003). Jews boycott German products (Varlegh \& Steenkamp, 1999). Chinese consumers boycott Japanese products (Ishii, 2009) and Ghandi called Indians to boycott British Salt (Klein, Smith, \& John 2004).

\section{Country Image Branding}

Consumers associate country-specific products through mental link (Aaker, 1991; Ettenson \& Gaeth, 1991) and make brand choices through attitude towards country-specific advertisements (Shimp, 1981). Attitude is affected by nation brand image whereby positive nation brand image may be used to gain competitive advantage in 
international marketing. (Parameswaran, \& Pisharodi, 1994) There are several ways to influence consumers' perceptions of product quality (Peterson \& Jolibert, 1995) and one of them is the country-of-origin (COO) construct.

COO has a direct effect on product evaluation (Bilkey \& Nes, 1982) and it can be used to fill in the gaps left behind by the lack of product information. (Johansson, Douglas \& Nonaka, 1985) COO also has an impact on perception of advertisements that promote foreign products. (Moon \& Jain, 2002) Consumers who are less familiar with the product category may tend to rely more on the country-of-origin information for product evaluation (Min Han, 1989). Past research works in COO had amplified the importance of nation branding: a nation that seeks to improve its image in an international market increases its strength of country-of-origin attribute and its country image. (Fan, 2006) Nation brand image has a greater effect on purchasing decision/willingness to buy as compared to product image(Han \& Terpstra, 1988). However, such findings may not be applicable for a given country where cognitive and affective nation brand image are not consistent. In such case where inconsistency arises, affective nation brand image serves as a better predictor for willingness to buy. (Wang, Li, Barnes \& Ahn, 2012)

Researchers have also discovered that country image can be factored into two broad categories: (i) socioeconomic factor of the country image and (ii) geocultural factor of the country image. Socioeconomic factor creates more likelihood in negative emotions such as animosity whereas geocultural factor creates more likelihood in positive emotions such as reminiscent (Brijs, Bloemer \& Kasper, 2011). Consumers are more inclined to react negatively when socio-economics issues arise, leading to a possible staunch in unwillingness to buy foreign products from hostile nation.

\section{Conceptual Framework}

Consumer animosity is country or culture specific (Rose, Rose, \& Shoham, 2009) and culture plays an important role that accounts for the relationship between the antecedent of ethnicity and the result of animosity. (Richardson, 2012) Although much study has done on consumer ethnocentrism using CETSCALE to measure the level of consumers' ethnocentrism, little study is done on measuring consumer animosity at the country or culture specific level. CETSCALE is not country or culture specific (Klein, Ettenson \& Morris, 1998) and hence it may not be appropriately applicable for the study of consumer animosity that is country-specific in nature. In addition, study has shown that little correlation is observed in out-group behaviour arising from animosity with ethnocentrism - a clear indication that animosity and ethnocentrism are mutually exclusive constructs. (Nijssen \& Douglas, 2004; Jiménez \& San Martín, 2010)

Similar to Richardson's (2012) research work, this paper offers a similar approach in understanding animosity. This paper examines the effect of a consumer's level of tolerance as an antecedent to consumers' animosity.

Cosmopolitanism (COS) is a view that regards the whole world more than locality and it plays a mediating role in explaining animosity. (Cannon, \& Yaprak, 2002) It is also more pronounced in an individualistic society. COS is likely fostered within relationship-oriented cultures where collectivism is more evident as compared to agentic-oriented cultures where individualism is more evident. (Cleveland, Erdoğan, Arıkan, \& Poyraz, 2011) Attention to cultural behaviour such as the collectivist behaviour also has an impact on how consumers respond to domestic or foreign products. (Russell \& Russell, 2006) Hence, the first proposition looks into the impact of the level of cosmopolitanism on consumers' animosity.

\section{Proposition 1}

Individualism-Collectivism behaviour of Indonesians affects level of cosmopolitanism, resulting to greater or lesser sensitivity in consumers' animosity.

In marketing literature, little research has done on how the level of consumers' tolerance affects animosity and the willingness to buy foreign products from hostile country. The relationship between the levels of tolerance as a construct for willingness to buy is mediated by the degree of self-transcendence of the consumers and self-transcendence is a value that consumers personally hold as an individual. It also influences willingness to buy. Additionally, affinity through acceptance by tolerating hostility is found non-bipolar, forming a different construct from animosity. (Nes, Yelkur \& Silkoset, 2014) Such findings prompt a research in understanding how consumers' affinity interacts with animosity to influence willingness to buy foreign products from hostile nation. For example, consumers are more willing to tolerate and buy foreign products from hostile nation when they possess higher level of spirituality or self-transcendence. An example of such forgiveness is seen in the case study of Australians forgiving the French after a nuclear test in 1995. (Heslop, Lu, \& Cray, 2009) Hence, the 
third proposition looks into the effects of consumers' level of tolerance on willingness to buy, mediated by consumers' level of self-transcendence.

\section{Proposition 2}

Indonesians' level of self-transcendence influence level of tolerance and high tolerance level due to strong self-transcendence leads to greater forbearance and more willingness to buy foreign products from hostile nation.

\section{Discussion and Conclusion}

According to United Nations, in year 2011, Indonesia's imports were $87 \%$ of its exports, indicating an active import policy as compared to the export policy. Indonesia's imports stand at 21\% of its GDP. (UN Country Data for Indonesia) With these data in mind, LeVine \& Campbell's (1972) and Russell \& Russell's (2006) propose that consumers in countries that have high level of foreign trade are more sensitive towards animosity. This is also seen in cases when domestic alternatives that produce low quality may not provide an appropriate substitution for products from hostile nations. Although domestic products are widely sold in Indonesia, competitive products with good quality in comparative to stronger foreign brands are not evident in the market. Thus, high foreign trade activities may instigate protectionism. Moreover, Indonesia is a collectivistic society and $\operatorname{COS}$ is less pronounced in a collectivistic society. When COS is less pronounced, consumers favour locality over universality and shield its local environment or society from external threats or offerings.

The existing literature offers little explanation on the mediating roles of tolerance level between consumers' animosity and willingness to buy foreign products from hostile nations. Despite the abundance of research in consumers' animosity and its antecedents, little is known about how animosity is adjusted or moderated using psychological forces such as level of tolerance to improve willingness to buy. This paper attempts to contribute to existing literature through providing a conceptual framework that observes the roles of level of tolerance in a collectivist society.

The arguments presented in this paper have several managerial implications. Managers who wish to build strong international brand image should adhere to the importance of nation brand image and its role in affecting consumers' animosity. Managers can moderate the advertising effort and improve customer relationship by sympathizing with the offended consumers in exchange for greater level of tolerance. Although negative emotions may easily overwhelm consumers, managers may better position themselves as sympathizing partners in the society for the future when nation's brand image improves.

This study is important for several reasons. First, the study promises a significant contribution to the marketing literature in area of consumers' animosity. Although much has been studied in consumers' animosity and its antecedents, little is known about the psychological factors in a country-specific study. Last, the present conceptual framework improves the existing models developed by researchers. The improvement includes psychological constructs (i.e. affinity by level of tolerance) that could help explain consumers' willingness to buy.

This study is constrained by limitations which can be addressed in future studies. First, there is limited empirical evidence to support the relationships between constructs in the conceptual framework. Although most of the research works looked into consumers' animosity and willingness to buy, little empirical evidence is found to study relationships between antecedents and consequences. Additionally, little is known of causality between constructs in the conceptual model. The conceptual framework presented in this paper is testable in future studies. The measure of animosities, level of tolerance and willingness to buy may prove to be valuable when data analysis (i.e. textual analysis and Structural Equation Modeling) is used to study the underlying concepts and itsdirect, indirect and total effects of variables.

\section{References}

Aaker, D. A. (1991). Managing Brand Equity. New York: The Free Press.

Alden, D. L., Kelley, J. B., Riefler, P., Lee, J. A., \& Soutar, G. N. (2013). The Effect of Global Company Animosity on Global Brand Attitudes in Emerging and Developed Markets: Does Perceived Value Matter? Journal of International Marketing, 21(2), 17-38. http://dx.doi.org/10.1509/jim.12.0086

Amine, L. S., Chao, M. C. H., \& Arnold, M. J. (2005). Exploring the Practical Effects of Country of Origin, Animosity, and Price-Quality Issues: Two Case Studies of Taiwan and Acer in China. Journal of International Marketing, 13(2), 114-150. http://dx.doi.org/10.1509/jimk.13.2.114.64855 
Ang, S. H., Jung, K., Kau, A. K., Leong, S. M., Pornpitakpan, C., \& Tan, S. J. (2004). Animosity towards economic giants: what the little guys think. Journal of Consumer Marketing, 21(3), 190-207. http://dx.doi.org/10.1108/07363760410534740

Averill, J. (1982). Anger and aggression: An essay on emotion. New York: Springer-Verlag

Bachelard, M. (2013, December 11). Indonesian Minister Urges Boycott of Australian Beef over Spying Row. Brisbane Times.

Bilkey, W. J., \& Nes, E. (1982). Country-of-origin effects on product evaluations. Journal of international Business Studies, 13(1), 89-100. http://dx.doi.org/10.1057/palgrave.jibs.8490539

Brijs, K., Bloemer, J., \& Kasper, H. (2011). Country-image discourse model: Unraveling meaning, structure, and function of country images. Journal of Business Research, 64(12), 1259-1269. http://dx.doi.org/10.1016/j.jbusres.2011.01.017

Blackwell, R. D., Miniard, P. W., \& Engel, J. F. (2006). Consumer behaviour. 10. Aufl., Mason.

Blumer, H. (1969). Symbolic Interactionism: Perspective and Method. Englewood Cliffs, NJ: Prentice Hall.

Bolt, A. (2013, October 3). Tony Abbott Secures a Refugee Deal. Herald Sun.

Braunsberger, K., \& Buckler, B. (2011). What motivates consumers to participate in boycotts: Lessons from the ongoing Canadian seafood boycott.Journal of Business Research, 64(1), 96-102. http://dx.doi.org/10.1016/j.jbusres.2009.12.008

Cannon, H. M., \& Yaprak, A. (2002). Will the real-world citizen please stand up! The many faces of cosmopolitan consumer behavior. Journal of International Marketing, 10(4), 30-52. http://dx.doi.org/10.1509/jimk.10.4.30.19550

Cleveland, M., Erdoğan, S., Arıkan, G., \& Poyraz, T. (2011). Cosmopolitanism, individual-level values and cultural-level values: A cross-cultural study. Journal of Business Research, 64(9), 934-943. http://dx.doi.org/10.1016/j.jbusres.2010.11.015

Cui, A. P., Wajda, T. A., \& Hu, M. Y. (2012). Consumer animosity and product choice: might price make a difference? Journal of Consumer Marketing, 29(7), 494-506. http://dx.doi.org/10.1108/07363761211275009

Ebenkamp, B. (2003). The American people: just say 'no' to escargot! Brandweek, 44, 20.

Elliott, G. R., \& Cameron, R. C. (1994). Consumer perception of product quality and the country-of-origin effect. Journal of International Marketing, 49-62. Retrieved from http://www.jstor.org/stable/info/25048542

Ettenson, R., \& Gaeth, G. (1991). Consumer perceptions of hybrid (bi-national products). Journal of Consumer Marketing, 8(4), 13-18. http://dx.doi.org/10.1108/07363769110035117

Fan, Y. (2006). Branding the nation: what is being branded? Journal of Vacation Marketing, 12(1), 5-14. http://dx.doi.org/10.1177/1356766706056633

Federn, E. (1985). The therapeutic management of violence. Milieu Therapy, 4, 41-49. http://dx.doi.org/10.1300/j007v07n02_02

Fray, P. (2014). Will asylum policy cost Australia's Abbott dear? BBC News Asia. Retrieved from http://www.bbc.com/news/world-asia-25807875

Han, C. M., \& Terpstra, V. (1988). Country-of-origin effects for uni-national and bi-national products. Journal of International Business Studies, 235-255. http://dx.doi.org/10.1057/palgrave.jibs.8490379

Heslop, L. A., Lu, I. R., \& Cray, D. (2009). Australian consumers' attitudes toward France a decade after nuclear testing: evidence of forgiveness. Journal of Consumer Behaviour, 8(4), 192-210. http://dx.doi.org/10.1002/cb.283

Ishii, K. (2009). Nationalistic Sentiments of Chinese Consumers: The Effects and Determinants of Animosity and Consumer Ethnocentrism. Journal of International Consumer Marketing, 21, 299-308. http://dx.doi.org/10.1080/08961530802282232

Jiménez, N. H., \& San, M. S. (2010). The role of country-of-origin, ethnocentrism and animosity in promoting consumer trust.The moderating role of familiarity. International Business Review, 19(1), 34-45. http://dx.doi.org/10.1016/j.ibusrev.2009.10.001 
Johansson, J., Douglas, S. P., \& Nonaka, I. (1985). Assessing the Impact of Country of Origin on Product Evaluations: A New Methodological Perspective. Journal of Marketing Research, 22, 388-396. http://dx.doi.org/10.2307/3151584

Jung, K., Ang, S. H., Leong, S. M., Tan, S. J., Pornpitakpan, C., \& Kau, A. K. (2002). A typology of animosity and its cross-national validation. Journal of Cross-Cultural Psychology, 33(6), 525-539. http://dx.doi.org/10.1177/0022022102238267

Kelly, P. (2012). I'll Turn Back Every Boat, says Tony Abbott.

Kirschbaum, E. (2003). Boycott of American Goods over Iraq War Gains. Common Dreams. Retrieved from http://www.commondreams.org/headlines03/0325-10.htm

Klein, J. G., Ettenson, R., \& Morris, M. (1998). The animosity model of foreign product purchase: An empirical test in the People's Republic of China. Journal of Marketing, 62(1), 89-100. http://dx.doi.org/10.2307/1251805

Klein, J. G. (2002). Us versus them, or us versus everyone? Delineating consumer aversion to foreign goods. Journal of International Business Studies, 33(2), 345-363. http://dx.doi.org/10.1057/palgrave.jibs.8491020

Klein, J. G., Smith, N. C., \& John, A. (2004). Why We Boycott: Consumer Motivations for Boycott Participation. Journal of Marketing, 68(July), 92-109. http://dx.doi.org/10.1509/jmkg.68.3.92.34770

Lee, A. M. (1955). Principles of sociology (No. 26). Barnes \& Noble.

Leong, S. M., Cote, J. A., Ang, S. H., Tan, S. J., Jung, K., Kau, A. K., \& Pornpitakpan, C. (2008). Understanding consumer animosity in an international crisis: nature, antecedents, and consequences. Journal of International Business Studies, 39(6), 996-1009.http://dx.doi.org/10.1057/palgrave.jibs.8400392

LeVine, R. A., \& Campbell, D. T. (1972). Ethnocentrism: Theories of conflict, ethnic attitudes, and group behavior. Oxford: John Wiley \& Sons.

Min Han, C. (1989). Country image: halo or summary construct? Journal of Marketing Research (JMR), 26(2). http://dx.doi.org/10.2307/3172608

Moon, B. J., \& Jain, S. C. (2002). Consumer processing of foreign advertisements: roles of country-of-origin perceptions, consumer ethnocentrism, and country attitude. International Business Review, 11(2), 117-138. http://dx.doi.org/10.1016/s0969-5931(01)00052-x

Mrad, S. B., Ye Sheng, S., \& Hart, L. K. (2013). Do Rumblings Lead to Real Action? A Case of Animosity and Boycott in China. International Journal of China Marketing, 3(2). Retrieved from http://t.www.na-businesspress.com/IJCM/MradSB_Web3_2_.pdf

Nes, E. B., Yelkur, R., \& Silkoset, R. (2014). Consumer affinity for foreign countries: Construct development, buying behavior consequences and animosity contrasts. International Business Review. http://dx.doi.org/10.1016/j.ibusrev.2013.11.009

Nijssen, E. J., \& Douglas, S. P. (2004). Examining the animosity model in a country with a high level of foreign trade. International Journal of Research in Marketing, 21(1), 23-38. http://dx.doi.org/10.1016/j.jiresmar.2003.05.001

Parameswaran, R., \& Pisharodi, R. (1994). Facets of country of origin image: an empirical assessment. Journal of Advertising, 23(1), 43-56. http://dx.doi.org/10.1080/00913367.1994.10673430

Park, C. S., \& Srinivasan, V. (1994). A survey-based method for measuring and understanding brand equity and its extendibility. Journal of Marketing Research (JMR), 31(2). http://dx.doi.org/10.2307/3152199

Parmar, A. (2004). Drink politics. Marketing News, 11-12.

Perdani, Y. (2013, November 22). Oz Should Apologize, Move On. The Jakarta Post.

Peterson, R. A., \& Jolibert, A. J. (1995). A meta-analysis of country-of-origin effects. Journal of International Business Studies, 26(4), 883-900. http://dx.doi.org/10.1057/palgrave.jibs.8490824

Richardson, C. W. Jr. (2012). Ethnicity or Nationality: A Cross-Cultural Extension of the Animosity Model of Foreign Product Purchase. International Journal of Business, Marketing, \& Decision Science, 5(2), 86-98. Retrieved

from http://connection.ebscohost.com/c/articles/84864423/ethnicity-nationality-cross-cultural-extension-animosit $\mathrm{y}$-model-foreign-product-purchase 
Riefler, P., \& Diamantopoulos, A. (2007). Consumer animosity: A literature review and a reconsideration of its measurement. International Marketing Review, 87-119. http://dx.doi.org/10.1108/02651330710727204

Rose, M., Rose, G. M., \& Shoham, A. (2009). The impact of consumer animosity on attitudes towards foreign goods: a study of Jewish and Arab Israelis. Journal of Consumer Marketing, 26(5), 330-339. http://dx.doi.org/10.1108/07363760910976583

Russell, D. W., \& Russell, C. A. (2006). Explicit and implicit catalysts of consumer resistance: the effects of animosity, cultural salience and country-of-origin on subsequent choice. International Journal of Research in Marketing, 23(3), 321-331. http://dx.doi.org/10.1016/j.jiresmar.2006.05.003

Shimp, T. A., \& Sharma, S. (1987). Consumer ethnocentrism: construction and validation of the CETSCALE. Journal of Marketing Research, 280-289. http://dx.doi.org/10.2307/3151638

Shimp, T. A. (1981). Attitude toward the ad as a mediator of consumer brand choice. Journal of Advertising, 10(2), 9-48. http://dx.doi.org/10.1080/00913367.1981.10672756

Shoham, A., Davidow, M., Klein, J. G., \& Ruvio, A. (2006). Animosity on the home front: the Intifada in Israel and its impact on consumer behavior. Journal of International Marketing, 14(3), 92-114. http://dx.doi.org/10.1509/jimk.14.3.92

UN Country Data for Indonesia, United Nation. Retrieved from $\mathrm{http} / / /$ data.un.org/CountryProfile.aspx?crName=indonesia

Varlegh, P. W. J., \& Steenkamp, J. E. (1999). A Review and Meta-Analysis of Country of Origin Research. Journal of Economic Psychology, 20, 521-546. http://dx.doi.org/10.1016/s0167-4870(99)00023-9

Witular, R. A. (2014). TNI Gears Up, Sets Sights on Foreign Threats. The Jakarta Post.

Wang, C. L., Li, D., Barnes, B. R., \& Ahn, J. (2012). Country image, product image and consumer purchase intention: Evidence from an emerging economy. International Business Review, 21(6), 1041-1051. http://dx.doi.org/10.1016/j.ibusrev.2011.11.010

Weiner, B. (1986). An Attributional Theory of Motivation and Emotion. New York: Springer-Verlag.

Weiner, B. (2000). Attributional Thoughts about Consumer Behavior. Journal of Consumer Research, 3, 382-387. http://dx.doi.org/10.1086/317592

\section{Copyrights}

Copyright for this articleis retained by the author(s), with first publication rights granted to the journal.

This is an open-access article distributed under the terms and conditions of the CreativeCommons Attribution license (http://creativecommons.org/licenses/by/3.0/). 